\title{
KINERJA DINAS KESEHATAN KABUPATEN MAMBERAMO TENGAH PADA PROGRAM KESEHATAN IBU DAN ANAK
}

\section{PERFORMANCE OF HEALTH OFFICE MAMBERAMO CENTRAL DISTRICT IN THE MOTHER AND CHILD HEALTH PROGRAM}

\author{
Semuel Tandi Salla', Andi Zulkifli ${ }^{2}$, Sukri Palutturi ${ }^{3}$ \\ 'Dinas Kesehatan Kabupaten Mamberamo Tengah \\ ${ }^{2}$ Departemen Epidemiologi, Fakultas Kesehatan Masyarakat, Universitas Hasanuddin \\ ${ }^{3}$ Departemen Administrasi dan Kebijakan Kesehatan, Fakultas Kesehatan Masyarakat, \\ Universitas Hasanuddin-
}

\begin{abstract}
*Alamat Korespondensi: Semuel Tandi Salla, Dinas Kesehatan, Kabupaten Mamberamo Tengah, Kobakma, 99558, Telp: 082198147799, Email: semts.md@yahoo.com
\end{abstract}

\begin{abstract}
ABSTRAK
Cakupan program kesehatan ibu dan anak di dinas kesehatan Kabupaten Mamberamo Tengah masih rendah berdasarkan indikator standar pelayanan minimal yang telah ditentukan dari Kementerian Kesehatan Republik Indonesia. Penelitian ini bertujuan menganalisis Kinerja Dinas Kesehatan Kabupaten Mamberamo Tengah pada Program Kesehatan Ibu dan Anak (KIA). Metode penelitian adalah kualitatif dengan pendekatan studi kasus. Informan sebanyak 12 orang yang adalah pimpinan dan pelaksana program kesehatan ibu dan anak di dinas kesehatan dan puskesmas. Pengumpulan data melalui observasi, telaah dokumen dan wawancara mendalam. Analisis data menggunakan content analysis. Hasil penelitian menunjukkan bahwa masih ada sebagian bidan puskesmas sebagai petugas di layanan program kesehatan ibu dan anak belum mampu dan terampil dalam menjalankan program tersebut dan sebagian petugas belum memiliki surat tanda registrasi bidan sebagai jaminan kualitas tenaga kesehatan. Ketersediaan dana masih kurang bagi sebagian puskesmas dan penggunaannya tidak tepat sasaran. Alokasi dana sebagian besar untuk sarana dan prasarana serta belanja pegawai. Selain itu terdapat keterlambatan dalam realisasi anggaran. Supervisi program belum berjalan secara rutin dan belum ada tim supervisi terpadu yang dibentuk oleh dinas kesehatan. Proses perencanaan program kesehatan ibu dan anak belum maksimal karena belum disusunnya rencana kerja tahunan oleh seksi kesehatan ibu dan anak serta perencanaan dari bawah (bottom up) oleh puskesmas belum dikerjakan. Disimpulkan bahwa pelaksanaan program kesehatan ibu dan anak di dinas kesehatan Kabupaten Mamberamo Tengah belum berjalan maksimal sesuai yang diharapkan.
\end{abstract}

Kata kunci : kinerja, program kesehatan ibu dan anak, dinas kesehatan

\begin{abstract}
The coverage of maternal and child health programs in the district health offices of Central Mamberamo is still low based on indicator of minimum service standard that has been determined from the Ministry of Health of the Republic of Indonesia. This study aims to analyze the performance of Central Mamberamo District Health Office on Maternal and Child Health Program (KIA). The research method is qualitative with case study approach. The informants were 12 people who were the leaders and implementers of maternal and child health programs in the health offices and puskesmas. Data collection through observation, document review and indepth interviews. Data analysis using content analysis. The result of the research shows that there are still some midwives of health center as an officer in health service program of mother and child have not been able and skilled in running the program and some officer do not have registration letter of midwife as health care quality assurance. The availability of funds is still lacking for some puskesmas and its use is not right on target. The allocation of funds is mostly for facilities and infrastructure and personnel expenditure. In addition there is a delay in the realization of the budget. Program supervision has not been run regularly and there is no integrated supervision team established by the health department. The process of planning of maternal and child health programs has not been maximized because the annual work plan has not been prepared by maternal and child health sectors and bottom up planning by puskesmas has not been done yet. It was concluded that the implementation of maternal and child health programs in the district health offices of Central Mamberamo has not run as expected.
\end{abstract}

Keywords : performance, the mother and child health program, public health office 


\section{PENDAHULUAN}

Indikator kesehatan dan

kesejahteraan masyarakat di suatu negara dapat dilihat dari Angka Kematian Ibu (AKI) dan Angka Kematian Bayi (AKB) di negara tersebut. Indonesia menjadi salah satu negara di Association of South East Asian Nation (ASEAN) yang memiliki AKI yang tinggi. Menurut data Survei Demografi dan Kesehatan Indonesia (SDKI) tahun 2007 AKI di Indonesia mencapai 228/100.000 kelahiran hidup. Tidak hanya AKI saja yang tinggi, AKB di Indonesia juga masih sangat tinggi yaitu sebanyak 35 bayi per seribu kelahiran hidup. Dengan jumlah penduduk Indonesia yang mencapai 225.642.000 jiwa, ada 9.774 ibu meninggal per tahun atau 1 orang ibu meninggal per jam dan 17 orang bayi meninggal per jam yang berkaitan dengan kehamilan, persalinan dan nifas (Balitbangkes, 2013).

Walaupun sudah menunjukkan penurunan yang signifikan, namun jika dibandingkan dengan negara ASEAN lainnya, AKI di Indonesia masih cukup tinggi. Oleh karena itu untuk mencapai target Millenium Development Goals (MDGs) 2015 yaitu AKI sebesar 102 per 100 ribu kelahiran hidup diperlukan upaya yang lebih keras dan strategis (Menkes, 2012). Guna memberikan panduan dalam melaksanakan urusan wajib pada bidang kesehatan telah ditetapkan Keputusan Menteri Kesehatan RI tentang Standar Pelayanan Minimal Bidang Kesehatan di kabupaten/kota. Standar Pelayanan Minimal (SPM) adalah tolok ukur kinerja pelayanan kesehatan yang diselenggarakan yang merupakan urusan wajib daerah yang berhak diperoleh setiap warga. Adapun pelayanan dasar adalah fungsi pemerintah dalam memberikan dan mengurus keperluan kebutuhan dasar masyarakat untuk meningkatkan taraf kesejahteraan rakyat (Menkes, 2008).

Guna memberikan panduan dalam melaksanakan urusan wajib pada bidang kesehatan telah ditetapkan Keputusan Menteri Kesehatan RI nomor : 741/MENKES/PER/VII/2008 tentang
Standar Pelayanan Minimal Bidang Kesehatan di kabupaten/kota. Standar Pelayanan Minimal (SPM) adalah tolok ukur kinerja pelayanan kesehatan yang diselenggarakan yang merupakan urusan wajib daerah yang berhak diperoleh setiap warga. Adapun pelayanan dasar adalah fungsi pemerintah dalam memberikan dan mengurus keperluan kebutuhan dasar masyarakat untuk meningkatkan taraf kesejahteraan rakyat (Menkes, 2008).

Data pada Dinas Kesehatan Kabupaten Mamberamo Tengah pada program kesehatan ibu dan anak menggambarkan cakupan program KIA tahun 2014 yaitu cakupan kunjungan ibu hamil K4 (ANC lengkap) sebesar 45,73\%, cakupan komplikasi kebidanan yang ditangani sebesar 73,16\%, cakupan pertolongan persalinan oleh tenaga kesehatan yang memiliki kompetensi kebidanan sebesar 53,65\%, cakupan pelayanan nifas sebesar $70,92 \%$, cakupan neonatus dengan komplikasi yang ditangani $70,41 \%$, cakupan kunjungan bayi sebesar $74,18 \%$, cakupan pelayanan anak balita sebesar $66,42 \%$, cakupan peserta KB aktif sebesar $41,83 \%$. Berdasarkan indikator SPM menunjukkan bahwa semua cakupan program KIA tersebut masih di bawah standar pencapaian target SPM.

Kinerja menurut Gibson (1987) dalam Sedarmayanti (2013) dipengaruhi tiga variabel yaitu : variabel individu, organisasi, dan variabel psikologi. Variabel individu dikelompokkan pada sub variabel kemampuan dan keterampilan, latar belakang dan demografis. Sub variabel kemampuan dan keterampilan merupakan faktor utama yang mempengaruhi perilaku dan kinerja individu. Variabel demografis mempunyai efek tidak langsung pada perilaku dan kinerja individu. Variabel organisasi, berefek tidak langsung terhadap perilaku dan kinerja individu. Variabel organisasi digolongkan dalam sub variabel sumber daya, kepemimpinan, imbalan, struktur dan desain pekerjaan.

Menurut Sedarmayanti faktor-faktor yang mempengaruhi kinerja, antara lain: sikap dan mental (motivasi 
kerja, disiplin kerja, dan etika kerja), pendidikan, ketrampilan, manajemen kepemimpinan, penghasilan, gaji dan kesehatan, jaminan sosial, iklim kerja, sarana dan prasarana, teknologi, dan kesempatan berprestasi.

Dalam aspek pelayanan kesehatan salah satu penyebab tingginya angka kematian ibu adalah karena pelayanan antenatal care dan pertolongan persalinan oleh tenaga profesional yang belum mampu terjangkau seluruh lapisan masyarakat. Keadaan ini menyebabkan masih banyak ibu tidak memeriksakan kehamilan dan banyak ibu hamil tidak mendapatkan pelayanan antenatal care yang sesuai standar. Penempatan bidan di desa diharapkan mampu memberikan kontribusi terhadap penurunan angka kematian ibu dan bayi serta berperan untuk meningkatkan persepsi peran masyarakat berperilaku hidup sehat dan bersih. Kegiatan bidan di desa pada umumnya meliputi kegiatan yang berkaitan dengan pelayanan KIA termasuk Keluarga Berencana, Pengelolaan program KIA dan pembinaan peran serta masyarakat dalam bidang kesehatan ibu dan anak (Menkes, 2014). Berdasarkan dari latar belakang masalah di atas, maka diajukan penelitian dengan judul Analisis Kinerja Dinas Kesehatan Kabupaten Mamberamo Tengah pada Program Kesehatan Ibu Dan Anak.

\section{BAHAN DAN METODE}

\section{Lokasi Penelitian dan Jenis Penelitian}

Pengumpulan data ini dilaksanakan di Kantor Dinas Kesehatan dan 5 (lima) Puskesmas Kabupaten Mamberamo Tengah pada bulan dan Desember 2016 Januari 2017. Desain penelitian yang dilakukan adalah penelitian kualitatif dengan menggunakan pendekatan studi kasus. Menurut Budiman (2011) pemilihan lokasi yang berbeda berguna untuk mengkaji variasi program, karena faktor pengelola program maupun perubahan kondisi dan program yang dilaksanakan pada banyak lokasi akan menunjukkan perbedaan yang penting dari satu tempat ke tempat lain.

\section{Populasi dan Sampel}

Informan dalam peneltian adalah kepala dinas, kepala seksi kesehatan ibu dan anak, kepala puskesmas ilugwa, kepala puskesmas kelila, kepala puskesmas eragayam, kepala puskesmas megambilis, kepala puskesmas kobakma, penanggungjawab kesehatan ibu dan anak puskesmas ilugwa, penanggungjawab kesehatan ibu dan anak puskesmas kelila, penanggungjawab kesehatan ibu dan anak puskesmas eragayam, penanggungjawab kesehatan ibu dan anak puskesmas megambilis, penanggungjawab kesehatan ibu dan anak puskesmas kobakma. Informan dalam penelitian sebanyak 12 orang.

\section{Teknik Pengumpulan Data}

Prosedur pengumpulan data pada penelitian ini dengan menggunakan metode wawancara mendalam, dokumentasi, rekaman arsip, observasi dan metode dokumentasi. Melalui penelitian ini pemecahan masalah penelitian dilakuakan dengan cara mendeskripsikan keadaan objek penelitian dengan institusi yang terkait berdasarkan fakta atau data.

Instrumen yang digunakan dalam penelitian ini yaitu kusioner yang dibuat dengan mengacu pada konsep teori.

\section{Metode Analisis Data}

Teknik analisis data dimulai dengan cara mengatur urutan data dengan cara mengorganisir data yang telah terkumpul, baik dari hasil wawancara mendalam, telaah dokumen, catatan lapangan, serta foto yang diambil sebagai bahan dokumentasi. Data yang terkumpul kemudian dikategorikan dan dipilah-pilah. Pemilahan dan pengkategorisasian data tersebut bertujuan untuk menemukan tema. Teknik analisa data dalam penelitian ini mengikuti petunjuk Miles dan Huberman yang melalui tiga alur yaitu reduksi data, penyajian data dan penarikan kesimpulan. 


\section{HASIL}

Penelitian ini berorientasi pada kinerja dinas kesehatan yang dilihat dari kemampuan dan keterampilan, ketersediaan dana sebagai sumber daya, supervisi program dari pimpinan, perencanaan program. Berdasarkan telaah dokumen profil Dinas Kesehatan Kabupaten Mamberamo Tengah tahun 2016, evaluasi capaian program KIA berpedoman pada standar pelayanan minimal yang telah ditentukan oleh Kementerian Kesehatan Republik Indonesia dengan indikator-indikator sesuai dengan target dan pencapaian cakupan kinerja program. Ada 12 indikator SPM yang berkaitan langsung dengan program KIA. Realisasi cakupan pada tahun 2016 masih di bawah target nasional yang sudah ditentukan oleh Kementerian Kesehatan. Ada beberapa indikator yang cakupannya masih rendah dan berkaitan langsung dengan kemampuan dan keterampilan bidan seperti pemeriksaan ibu hamil, pertolongan persalinan, imunisasi, dan pemasangan KB.

Dari hasil wawancara dari beberapa informan yang menyatakan bahwa :

"...bidan yang sudah berpengalaman itu biasanya terampil dalam menolong persalinan, tapi ada juga yang belum... baru sebagian juga belum punya STR (Surat Tanda Registrasi) bidan...kami rekrut saja karena untuk menutupi kekurangan tenaga... " (KP)

"...Bidan di wilayah kerja saya ini masih bidan baru lulus semua... jadi masih kurang terampil... mungkin karena pengalaman mereka masih kurang...tidak ada bidan koordinator (bikor) di sini yang mendampingi..." (CK)

"...saya belum pernah ikut pelatihan atau kursus, macam pelatihan APN (asuhan persalinan normal)...kitong (kami) di puskesmas kobakma ini ada 15 bidan tapi yang ikut pelatihan APN baru 3 orang saja..." (MM)

Dari wawancara pimpinan Dinas Kesehatan bahwa sebagian bidan masih kurang pengalaman kerja, pemberian pelatihan-pelatihan yang berkaitan dengan KIA masih sangat kurang dan bahkan ada sebagian yang belum pernah ikut pelatihan Asuhan Persalinan Normal. Kemudian di salah satu Puskesmas belum ada bidan koordinator (bikor) yang merupakan bidan senior yang seharusnya melakukan pendampingan kepada bidan-bidan yang baru lulus/tamat dan langsung dipekerjakan. Di samping itu masih ada beberapa tenaga bidan yang tidak memiliki STR (Surat Tanda Registrasi) bidan.

Pendanaan atau pembiayaan kesehatan dalam pelaksanaan Program KIA di Dinas Kesehatan Kabupaten Mamberamo Tengah tahun 2016 bersumber dari dana APBD Kabupaten dan dana tugas pembantuan BOK dari Kementerian Kesehatan. Dana APBD Kabupaten terdiri dari Dana Alokasi Umum (DAU), dana Otonomi Khusus (OTSUS) dan Dana Alokasi Khusus (DAK). Hasil telaah dokumen menunjukkan bahwa total anggaran serta alokasi anggaran masih lebih mengutamakan pembangunan fisik (sarana prasarana) dan belanja pegawai (administrasi perkantoran) dibanding program/kegiatan pelayanan dasar.

Selain itu, dari hasil wawancara terhadap beberapa informan dalam kaitannya dengan pembiayaan program KIA menyatakan bahwa:

"...dana untuk program KIA diambil dari dana BOK biasanya mereka pergunakan untuk kegiatan posyandu... sebagian juga dari dana BPJS, itu biasanya dorang pake untuk klaim pertolongan persalinan atau jasa pelayanan saja... sedangkan dana DAK, OTSUS dan DAU tidak kami alokasikan untuk program KIA... sebenarnya belum cukup...pemda masih mengutamakan pembangunan fisik jadi... " (MS)

"...hanya karena selain membiayai kegiatan ini juga kadang kami ini ada kebutuhan lain lagi jadi...macam rehab Polindes yang sudah lapuk tuh..."(MH)

"...biasanya kalau mau rujuk pasien ibu hamil risiko tinggi tuh kapus 
bilang kamu stop sudah pakai biayarujukan tidak ada uang untuk rujukan ibu hamil...dana dari dinas mereka kasih itu tidak cukup..." (FS)

“...wilayah kerja Puskesmas kami

19 kampung yang sangat berjauhan... ini membutuhkan biaya yang besar untuk transportasi bidan setiap bulan melaksanakan PWS KIA... akhirnya ada saja yang tidak bisa jalan tiap bulan..." $(K Y)$

“...dana yang mereka cairkan dari dinas tuh selalu terlambat ke puskesmas... ini kegiatan rutin sebenarnya dimulai dari januari... akhirnya program seperti KIA jadi terhambat..." (LG)

Dari wawancara informan Dinas Kesehatan mengatakan bahwa ketersediaan dana dalam menjalankan program di Kabupaten Mamberamo Tengah belum tepat sasaran karena masih lebih mengutamakan pembangunan fisik (sarana dan prasarana). Dana OTSUS dan DAU tidak dialokasikan untuk program KIA. Kemudian dari sebagian puskesmas mengatakan bahwa dana tidak cukup untuk biaya transportasi kegiatan KIA, biaya rujukan pasien, dan rehabilitasi polindes. Dana untuk salah satu puskesmas (Puskesmas Eragayam) terlambat di cairkan dari dinas kesehatan sehingga itu juga sangat berpengaruh dalam menjalankan program yang seharusnya sudah dimulai berjalan dari awal tahun.

Supervisi adalah kegiatan-kegiatan yang terencana seorang manajer melalui aktifitas bimbingan, pengarahan, observasi, motivasi dan evaluasi pada stafnya dalam melaksanakan kegiatan atau tugas seharihari. Kegiatan supervisi mengusahakan seoptimal mungkin kondisi kerja yang kondusif dan nyaman yang mencakup lingkungan fisik, beban kerja, dan prosedur kerja yang dibutuhkan untuk memudahkan pelaksanaan tugas. Berikut ini beberapa wawancara menyatakan bahwa:

"...kalau saya jarang turun ke lapangan untuk supervisi karena saya sifatnya hanya menerima laporan dari kepala seksi KIA...” (MS) “...dari dinas mereka jarang turun melakukan pendampingan atau supervisi untuk program KIA... iya mungkin hanya 2 kali setahun kah..." (AS)

“...sepanjang tahun ini kami belum pernah didampingi dari dinas kalau kegiatan posyandu..." (SS)

Dari hasil wawancara informan dari dinas kesehatan di atas disimpulkan bahwa supervisi program KIA dari pimpinan jarang dilakukan karena hanya mengharapkan laporan pencatatan dan pelaporan bulanan progam KIA dari puskesmas. Bahkan ada petugas puskesmas yang merasa tidak pernah ada pendampingan dalam kegiatan posyandu.

Perencanaan merupakan proses penentuan tujuan organisasi (perusahaan) dan kemudian menyajikan (mengartikulasikan) dengan jelas strategistrategi (program), taktik-taktik (tata cara pelaksanaan program) dan operasi (tindakan) yang diperlukan untuk mencapai tujuan perusahaan secara menyeluruh. Berikut ini hasil wawancara yang dilakukan kaitan dengan perencanaan program:

“...mengenai Renja SKPD tahunan belum kami susun...itu mungkin di bagian perencanaan program kah... SPM itu saja yang kami jadikan dasar sebagai target puskesmas... yang penting mereka laksanakan kegiatan rutin sesuai tupoksinya..." (KP)

$$
\text { “...dalam minilokakarya }
$$

puskesmas hanya membahas jadwal kegiatan rutin bulanan, termasuk kegiatan KIA...itu biasanya kami buat POA Puskesmas sebagai acuan dalam menjalankan kegiatan..." (AS)

"...kami ini hanya berpedoman pada penyusunan target tahunan yang sudah ditentukan dari dinas... tugas kami itu melaksanakan kegiatan rutin di KIA dan buat laporan bulanan untuk di kirim ke dinas..." (FS)

Dari hasil wawancara di atas disimpulkan bahwa dinas kesehatan tidak memiliki Renja SKPD tahunan yang jelas. Target pencapaian program KIA di 
puskesmas mengacu pada standar pelayanan minimal (SPM) yang telah ditentukan dari Kementerian Kesehatan. Namun ada satu puskesmas yang membahas POA (Plan of Action) program dalam minilokakarya puskesmas sebagai acuan dalam menjalankan program KIA.

\section{PEMBAHASAN}

Berdasarkan pengamatan/observasi terlihat jelas bahwa PNS yang sudah berpengalaman jumlahnya masih jauh lebih sedikit sehingga dilakukan perekrutan tenaga honorer yang kebanyakan masih lulusan baru yang masih kurang dalam pengalaman kerja. Selain itu, sebagian bidan belum pernah ikut pelatihan-pelatihan seperti pelatihan Asuhan Persalinan Normal (APN). Padahal pelatihan Asuhan Persalinan Normal (APN) adalah salah satu syarat dalam meningkatkan kemampuan dan keterampilan tenaga bidan. Bahkan ada puskesmas belum ada bidan koordinator (bikor) yang merupakan bidan senior sebagai pendamping. Perekrutan tenaga tersebut tidak dibarengi dengan jaminan mutu tenaga bidan sehingga persyaratan STR (Surat Tanda Registrasi) bidan tidak terlalu dianggap penting.

Penelitian yang sama yang di lakukan oleh Asikin (2012) di Puskesmas Samata dan Puskesmas Bontolempangan Kabupaten Gowa mengemukakan bahwa dampak dari masih rendahnya kualitas bidan di Puskesmas menyebabkan program KIA tidak berjalan optimal dikarenakan minimnya pelatihan-pelatihan yang diikuti oleh bidan sebagai petugas KIA. Kemudian penelitian oleh Aryanti (2010) di Puskesmas Di Kabupaten Purbalingga mengatakan bahwa hasil pengamatan yang dilakukan pada saat bidan melakukan pelayanan antenatal diperoleh hasil ratarata keseluruhan $65,85 \%$, masih di bawah standar yaitu $75 \%$.

Ketersediaan dana dalam menjalankan program di Kabupaten Mamberamo Tengah belum tepat sasaran karena persentase alokasi dana untuk program KIA pada tahun 2016 yaitu hanya sebesar 4,2 \%. Sebagian besar alokasi anggaran untuk pembangunan fisik sarana dan prasarana serta belanja pegawai. Sebagian puskesmas mengatakan bahwa dana tidak cukup untuk biaya transportasi kegiatan KIA, biaya rujukan pasien, dan rehabilitasi polindes dan terlambat di cairkan dari dinas kesehatan sehingga itu juga sangat berpengaruh dalam menjalankan program yang seharusnya sudah dimulai berjalan dari awal tahun.

Penelitian dari Dodo et al (2012) di Kabuapten Sabu Raijua mengatakan bahwa komitmen pemerintah masih rendah dalam pembiayaan program KIA sebagai program prioritas, serta keterlambatan pencairan dana mengganggu implementasi kegiatan dan memberi peluang terjadinya penyalahgunaan/korupsi sehingga fungsi pengawasan harus ditingkatkan baik secara internal maupun ekternal. Penelitian ini juga didukung oleh penelitian yang dilakukan oleh Saefudin (2007) pada puskesmas di Kota Banjar Jawa Barat mengatakan bahwa realisasi dan kecukupan anggaran di puskesmas guna pelaksanaan program KIA sangat memadai karena didukung dari berbagai sumber dana yang meliputi Anggaran Pendapatan Belanja Daerah (APBD) Kota, PKPS BBM/JPKMM, APBD Propinsi dan APBN, dan untuk APBD Kota dan JPKMM.

Masalah dalam pembiayaan kesehatan di Indonesia adalah belum optimalnya efektivitas dan efisiensi dalam penggunaan. Hal ini terkait erat dengan jumlah dana yang kurang, alokasi yang tidak sesuai prioritas, dan pola belanja yang cenderung pada investasi barang dan kegiatan tidak langsung. Dominannya belanja investasi dan kegiatan tidak langsung berdampak pada kurangnya biaya operasional dan biaya untuk kegiatan langsung. Di sisi lain, kinerja suatu program kesehatan sangat ditentukan oleh kecukupan biaya operasional dan biaya untuk kegiatan langsung. Kondisi ini diperburuk lagi dengan terlambatnya pencairan dana yang secara umum 
mempengaruhi pencapaian target program (Ahmad \& Padang, 2010).

Prinsip pokok supervisi adalah untuk lebih meningkatakan kinerja bawahan, dengan melakukan pengamatan langsung terhadap pekerjaan bawahan, kemudian apabila ditemukan masalah, segera diberikan petunjuk atau bantuan untuk mengatasinya. Supervisi harus dilakukan secara teratur atau berkala dengan frekuensi lebih sering lebih baik. Strategi dan tata cara supervisi yang dilakukan harus sesuai dengan kebutuhan masing-masing bawahan secara individu.

Penelitian

Bradley

(2013)

mendapatkan kesimpulan bahwa supervisi merupakan komponen penting dalam manajemen sumber daya manusia. Pada penelitian ini yang bertugas dalam melakukan supervisi bukan hanya seorang bidan koordinator namun terdapat sebuah tim yang terdiri dari tenaga kesehatan dari berbagai disiplin ilmu yang melakukan supervisi terpadu untuk mengkaji berbagai aspek dalam kinerja pelayanan. Ditambahkan juga bahwa supervisi yang dilakukan termasuk menghabiskan waktu bersama dengan tenaga kesehatan yang disupervisi, hal ini merupakan komponen penting dari sebuah supervisi. Adanya observasi harian dan obsevasi terhadap teknik pelayanan bidan, dan diakhiri dengan tindak lanjut dengan membahas kekuatan dan kelemahan bidan serta rencana untuk meningkatkan pelayanan merupakan kegiatan yang harus ada pada tiap supervisi yang dilakukan, namun semua hal ini dapat dilakukan oleh seorang supervisor yang memiliki pengetahuan dan keterampilan yang baik pula.

Penelitian oleh Gusna (2012) di

Dinas Kesehatan Kabupaten Padang Pariaman mengatakan bahwa hambatan dalam melakukan supervisi adalah kurangnya motivasi supervisor dalam menggali masalah, berbagi, hingga mencari solusi untuk penanganan setiap masalah yang ditemui oleh bidan di desa sehingga supervisi yang dilakukan oleh bidan koordinator (bikor) sehingga hasil cakupan antenatal care K4 Program KIA masih rendah pada tahun 2012. Kemudian oleh Fatkhiyah (2015) pada bidan pelaksana di Tegal yang mengatakan bahwa secara bersama-sama variabel motivasi dan kualitas supervisi berpengaruh terhadap kepatuhan bidan dalam deteksi preeklampsia. Ada kecenderungan bahwa semakin kurang motivasi bidan maupun kualitas supervisi yang dilaksanakan oleh bidan koordinator, maka bidan semakin tidak patuh dalam melaksanakan deteksi preeklampsia sesuai standar prosedur operasional.

Kepatuhan bidan menerapkan standar pelayanan kebidanan bagi kesehatan ibu dan anak berdampak dan mempunyai daya ungkit terhadap kualitas pelayanan antenatal yang diberikan, yang selanjutnya berkontribusi terhadap penurunan angka morbiditas dan mortalitas pada ibu dan bayi. Terdapat cukup bukti yang menunjukkan masih rendahnya kualitas pelayanan kesehatan di tingkat masyarakat, seperti studi yang dilakukan di Indonesia oleh D'Ambruoso, (2009) yang menyatakan bahwa pelayanan kebidanan yang diberikan oleh bidan masih di bawah standar pelayanan. Penelitian Prual,et.all di Nigeria (2011) menyebutkan kualitas pemeriksaan faktor risiko selama konsultasi antenatal memiliki efektivitas dalam mencegah dan memprediksi komplikasi obstetrik. Didukung penelitian Mathole di Zimbabwe (2011) yang menyatakan kunjungan antenatal yang pertama kali dapat mendeteksi komplikasi kehamilan.

Hasil dari hasil wawancara dengan pimpinan di tingkat dinas kesehatan bahwa penyusunan Renja SKPD di tingkat Seksi KIA belum berjalan dan hanya berpedoman pada indikator standar pelayanan minimal (SPM) yang telah ditentukan dari Kementerian Kesehatan. Adapun salah satu puskesmas menyusun POA melalui miniokakarya bulanan pada tingkat puskesmas dan dijadikan acuan dalam menjalankan program di wilayah kerja puskesmas tersebut.

Perencanaan pelayanan program KIA adalah sebuah proses untuk 
merumuskan masalah-masalah program KIA yang akan dilaksanakan di masa yang akan datang untuk mencapai tujuan yang dikehendaki, serta pemantauan dan penilaian atas perkembangan hasil pelaksanaan yang dilakukan secara sistematis dan berkesinambungan. Untuk itu sebelum merencanakan pelayanan program KIA harus dilakukan analisis situasi, mengidentifikasi masalahnya serta menentukan prioritasnya, menetapkan tujuannya, mengkaji hambatan dan kelemahannya serta menyusun rencana kerja operasional.

Salah satu sistem perencanaan adalah perencanaan dengan pendekatan partisipatif dilaksanakan dengan melibatkan semua pihak yang berkepentingan terhadap pembangunan. Pelibatan mereka adalah untuk mendapatkan aspirasi dan menciptakan rasa memiliki. Para profesional perawatan kesehatan dan organisasi profesi memiliki peran utama untuk memainkan posisi dalam proses peningkatan kesehatan ibu dan anak. Mereka merupakan organisasi para profesional yang sangat terlatih, dan mereka tinggal dan bekerja di negaranegara di seluruh dunia (Chamberlain et al, 2007).

Organisasi profesi kesehatan atau Health Care Professional Organizations (HCPOs) yang terdiri dari anggota dalam kemitraan untuk kesehatan ibu dan anak yaitu Partnership for Maternal Newborn and Child Health (PMNCH). Para profesional perawatan kesehatan dan organisasi profesi kesehatan sangatlah penting dalam keberhasilan dan keberlanjutan sejumlah kegiatan seperti: meningkatkan kesehatan dan menangani penyakit dalam bidang kesehatan perempuan, reproduksi, kehamilan, pertolongan persalinan, kesehatan bayi, anak dan remaja, mengajar dan melatih tenaga professional pada pelayanan layanan kesehatan ibu dan anak pada pelayanan perorangan disemua tingkatan, menetapkan standard sebagai bukti yang berbasis kurikulum kesehatan ibu, bayi, dan anak, intervensi, strategi layanan persalinan, dan pendidikan pada tingkat nasional, regional,dan global, serta monitoring kesehatan bidang perawatan dan persalinan, memberikan kepemimpinan dan pendampingan dalam perencanaan, pelaksanaan, dan monitoring program, melakukan advokasi peningkatan kesehatan ibu, bayi, dan anak serta untuk meningkatkan perhatian dalam memperkuat sistem kesehatan yang terkait (WHO, 2006).

Peran yang mungkin organisasi profesi terapkan pada negara-negara berkembang sangatlah banyak dan memiliki potensi untuk mengurangi angka kematian ibu. Upaya FIGO mencegah perdarahan post partum dengan pola kemitraan antara Akademi Peditarik Amerika (AAP) dengan Dinas Kesehatan India (IHS) selama 40 tahun merupakan contoh bagaimana dan mengapa peran organisasi profesi kesehatan sangat penting dalam memimpin advokasi untuk KIA.

Hasil penelitian dari Iswarno (2013) pada program kesehatan ibu dan anak (KIA) di Kabupaten Kepahiang mengatakan bahwa keterlibatan stakeholder lokal dalam proses perencanaan dan penganggaran program masih kurang, koordinasi antara dinas kesehatan dengan stakeholder kunci dalam perencanaan dan penganggaran juga tidak berjalan dengan baik, sehingga sering terjadi perbedaan pemahaman tentang program. Selain itu kualitas perencanaan kegiatan dinilai masih rendah, dan lemahnya advokasi dinas kesehatan sehingga berdampak pada kecilnya alokasi anggaran untuk program KIA.

\section{KESIMPULAN DAN SARAN}

Dari pemaparan hasil dan pembahasan penelitian ini, maka analisis kinerja program KIA di seluruh Puskesmas Kabupaten Mamberamo Tengah dapat disimpulkan bahwa Kemampuan dan keterampilan dari sebagian petugas program KIA di Puskesmas se Kabupaten Mamberamo Tengah masih rendah. Ketersediaan dana yang dialokasikan oleh Pemerintah Kabupaten Mamberamo 
Tengah melalui APBD Kabupaten masih lebih mengutamakan pembangunan fisik sarana dan prasarana serta belanja pegawai. Supervisi program dari pimpinan instansi Dinas Kesehatan dan bidan koordinator (bikor) terhadap pelaksanaan program KIA di Kabupaten Mamberamo Tengah masih jarang dilakukan, tidak rutin dan bahkan belum ada pembentukan tim supervisi terpadu yang jelas. Perencanaan program KIA di tingkat Dinas Kesehatan dan Puskesmas se Kabupaten Mamberamo Tengah belum optimal karena belum tersusunnya renja tahunan SKPD dan sistem perencanaan dari tingkat puskesmas belum berjalan. Berdasarkan hasil penelitian disarankan merencanakan dan membuat pelatihan-pelatihan untuk peningkatan kapasitas kemampuan dan keterampilan para tenaga kesehatan terkait dengan program kesehatan ibu dan anak, membuat perencanaan anggaran yang sesuai dengan petunjuk teknis, mengadvokasi tim anggaran pemerintah daerah dalam penyusunan anggaran, menyusun tim supervisi terpadu dari Dinas Kesehatan yang dikoordinir oleh bidan koordinator (Bikor), serta membentuk tim perencanaan program untuk menyusun Renja tahunan SKPD.

\section{DAFTAR PUSTAKA}

Ahmad, A. W., \& Padang, J. A. P. N. (2010). Dampak Desenteralisasi Fisikal Terhadap Outcomes Bidang Kesehatan (Studi Empiris Di Kabupaten/Kota Provinsi Sumatera Barat. (Tesis). Medan : Universitas Sumatera Utara.

Aryanti. (2010). Analisis Kualitas Pelayanan Antenalat Oleh Bidan Di Puskesmas Kabupaten Purbalingga. (Tesis). Semarang : Universitas Diponegoro.

Asikin. (2012). Karakteristik Individu dan Karakteristik Organisasi Pengaruhnya terhadap Motivasi dan Kinerja Bidan Puskesmas Samata dan Puskesmas Bontolempangan

\section{Kabupaten Gowa. (Skripsi).} Makassar : STIKES.

Balitbangkes. (2013). Riset Kesehatan Dasar. Jakarta: Badan Penelitian Dan Pengembangan Kesehatan, Jakarta.

Budiman. (2011). Penelitian Kesehatan. Jakarta: Penerbit Rafika Aditama, Jakarta.

Chamberlain J, McDonagh R, Lalonde A, Arulkumaran S. (2007). The Role of Professional Associations in Reducing Maternal Mortality Worldwide. Interudimannational Journal of Gynecology \& Obstetrics, 83(1):94-102.

Dodo D., Trisnantoro L. \& Ryarto S., (2012). Analisis Pembiayaan Program Kesehatan Ibu Dan Anak Bersumber Pemerintah Dengan Pendekatan Health Account. Jurnal Kebijakan Kesehatan Indonesia, 01:13-23.

Bradley S. (2013). District Health Manager's Perceptions Of Supervision In Malawi And Tanzania. Biomed central of Journal,11(43):1-8.

D'Ambruoso, et.al. (2009).Confidential Inquiries Into Maternal Death: Modifications and Adaption in Ghana and Indonesia. Journal of Gynecology and Obstetrics, 106:8084.

Fatkhiyah. (2015). Motivasi, Kualitas Supervisi dan Keparuhan Bidan Dalam Mendeteksi Preeklamsia. Jurnal Kesehatan Masyarakat, 10(2): 195-202.

Gusna. (2016). Analisis Cakupan Antenatal Care K4 Program Kesehatan Ibu dan Anak di Wilayah Kerja Dinas Kesehatan Kabupaten Padang Pariaman. Jurnal Kesehatan Andalas, 5(1).

Iswarno. (2013). Analisis Untuk Penerapan Kebijakan: Analisis Stakeholder dalam Kebijakan Program Kesehatan Ibu dan Anak Di Kabupaten Kepahiang. Jurnal 
Kebijakan Kesehatan Indonesia, 02: 77-85.

Lalonde AB. (2009). Delivering Services and Influencing Policy: Health Care Professionals Join Forces to Improve Maternal, Newborn, and Child Health. International Journal of Gynaecology and Obstetrics: The Official Organ of the International Federation of Gynaecology and Obstetrics. International Journal Federation of Gynecology and Obstetrics, 105(3):271.

Mathole. (2011). Dillemas and Paradoxes in Providing and Changing antenatal care:a Study of Nurse and midwives in Rural Zimbabwe. Heapol Oxford Journals, 046: 385393.

Menkes. (2008). Standar Pelayanan Minimal. Jakarta: Kementerian Kesehatan, Jakarta.

Menkes. (2012). Target MDGs Tahun 2015. Jakarta: Kementerian Kesehatan, Jakarta.

Menkes. (2014). Kebijakan Kemenkes Tentang Program KIA. Jakarta : Kementerian Kesehatan, Jakarta.

Prual. (2011). Effectieness of External Inspection of Compliance with
Standards in Improving Healthcare Organization Behavior and Healthcare Profesional Behavior. Department of Publish Health. Journal University of Oxford, 4(6).

Sedarmayanti. (2013). Good Governance (Kepemerintahan yang baik) Membangun Sistem Manajemen Kinerja Guna Meningkatkan produktivitas Menuju Good Government. Bandung: PT. Mayar Maju, Bandung.

WHO. (2006). The Role Of Health Care Professional Organizations in The Partnership for Maternal Newborn and Child Health. Geneva: WHO. 